The Nature and Application of Biocontrol Microbes III: Pseudomonas spp.

Presented at the Annual Meeting of The American Phytopathological Society,

August 1, 2005, Austin, TX

\title{
Diversity and Ecology of Biocontrol Pseudomonas spp. in Agricultural Systems
}

\author{
Brian B. McSpadden Gardener
}

Department of Plant Pathology, 1680 Madison Ave., The Ohio State University, OARDC, Wooster 44691-4096.

\begin{abstract}
McSpadden Gardener, B. B. 2007. Diversity and ecology of biocontrol Pseudomonas spp. in agricultural systems. Phytopathology 97:221-226.

Diverse Pseudomonas spp. may act as biological controls of plant pathogens, but the ecology of those natural populations is not well understood. And, while biocontrol potential has been identified in multiple pseudomonad strains, the linkages between genotype and phenotype have yet to be fully delineated. However, intensive studies of one class of biocontrol strains, i.e., those that can produce 2,4-diacetylphloroglucionl (DAPG), have provided new insights into the diversity, distribution, and interactions of biocontrol pseudomonads. Those studies also laid the foundation for future research and development of pseudomonad-based biocontrol strategies. Over the past several years, numerous studies have also revealed that biocontrol pseudomonads are widely distributed in

alter the rhizosphere abundance of DAPG producers in complex ways. Such studies provide support for the hypothesis of an ecological feedback mechanism whereby a native biocontrol population increase and subsequently reduce root disease severity following infection. It is well established that complex biological interactions can take place among biocontrol pseudomonads, plant pathogens, their hosts, and other members of the microbial community. The net result of such interactions likely dilutes biocontrol efficacy at the field scale. Nonetheless, inoculation can be effective, and several successful applications of biocontrol pseudomonads have been developed. Future applications of microbial ecology research will hopefully improve the consistency and efficacy of biocontrol mediated by Pseudomonas spp. Current applications and future opportunities for improving pseudomonad-based biological control are discussed.
\end{abstract} agricultural soils, and that multiple crop and soil factors can affect their abundance and activities. Recent work has shown that a variety of farm management practices that reduce soilborne disease pressure can also
Additional keywords: phlD, phyllosphere.
Diversity of biocontrol pseudomonads. Because the search for biocontrol agents typically relies on functional screens, only the most active isolates are typically identified. However, the biocontrol potential of strains that do not perform well in the bioassays used for selection is rarely assessed. Thus, it is unclear what the distribution of biocontrol activities is within different species of pseudomonads. Among the 94 Pseudomonas spp. named in the Approved Lists of Bacterial Names published in 1980 (65), those most commonly reported to harbor strains that can suppress plant diseases include $P$. aureofaciens, $P$. chlororaphis, $P$. fluorescens, and $P$. putida. Additionally, nonpathogenic isolates of $P$. syringae have been identified as useful biocontrol agents (29,30). Strains of two newly named pseudomonad species, $P$. brassicacearum and $P$. thevervalensis, also have been shown to be inhibitory to plant pathogen growth (60). Thus, it seems likely that additional lineages with biocontrol activity have yet to be discovered. However, it seems premature to suggest that most strains of these novel species are functionally inactive in terms of biological control, given the limited scope of the functional screens applied.

Corresponding author: B. B. McSpadden Gardener; E-mail address: bbmg+@ osu.edu

DOI: 10.1094/PHYTO-97-2-0221

(c) 2007 The American Phytopathological Society
Biocontrol activities have been reported in a number of pseudomonad strains; however, there does not appear to be a strict relationship between biocontrol activity and phylogeny. This may be due, in part, to the occurrence of biocontrol-associated genes on plasmids or other mobile elements. However, most genes currently associated with biocontrol activities in pseudomonads, such as the siderophore and antibiotic biosynthesis genes and the regulators thereof, appear to be fixed to the chromosome (37). Nonetheless, the lack of comprehensive investigations into the functional diversity and phylogeny of the various Pseudomonas species currently obscures the evolutionary origins and distribution of biocontrol genes within the genus. If there is a general lack of association between biocontrol functions and chromosomal phylogeny at the species level, it might be more useful to consider the question of whether biocontrol can be associated directly with phylogenetically distinct subspecies. Subspecies diversity can be delineated readily by the use of several different genotypic and/or phenotypic traits, but such studies sometimes lead to ambiguous and overlapping classifications even at the species level. For example, discrepancies between 16S-based phylogenies and biochemical assays have led to a call for the reclassification of $P$. fluorescens and $P$. putida (7); but, to date, no comprehensive revision of these species has been completed. Such a revision might provide the firm taxonomic framework that is required to understand the evolution and ecological significance of biocontrol activities within the genus. 
Despite the lack of association of phylogenetic variation with biocontrol phenotypes, the genetic diversity of pseudomonads has been defined at multiple levels using a variety of methods. Yamamoto et al. (71) showed that the sequences of just two conserved single copy genes can be used to classify isolates to the species level, but this approach has yet to be taken up by biocontrol researchers. This approach would be particularly useful in placing newly cultured strains within a standardized phylogenetic framework. To date, comprehensive genetic studies of pseudomonad biocontrol agents have only been conducted on one class of biocontrol pseudomonads, i.e., those that produce 2,4-diacetylphloroglucinol (DAPG). Researchers studying this group of pseudomonads have used a variety of methods including genomic fingerprinting, restriction fragment length polymorphism (RFLP) analyses of amplified genes, and gene sequences $(16,40,46,58$, $60,67)$. Such studies revealed multiple subspecies with varying levels of resolution. Despite differences in the strain collections analyzed in each study, certain subspecies were consistently identified. For example, genomic fingerprinting using random amplified polymorphism DNA and repetitive sequence basedpolymerase chain reaction (PCR) led to nearly identical results as RFLP analyses of the phlD gene $(40,46,47)$. These types of finescale taxonomic studies also have proven useful at identifying subspecies genotypes that differ in their host preference $(5,34,45)$, a trait likely to influence biocontrol efficacy. Extremely fine degrees of genotypic variation have also been found using genomic subtraction of closely related isolates (39). However, the full significance of this and other forms of subspecies genetic variation in these biocontrol pseudomonads has yet to be established.

One goal of conducting genetic diversity studies is to use genotypic information to make predictions about complex and more difficult to assay phenotypes, such as biological control potential. Within Pseudomonas spp., clonal growth appears to be the dominant mode of propagation, and genotypes have been linked strongly with various genotypes. For example, studies of carbon-source utilization profiles have shown that there is a high degree of concordance between genetic classifications of pseudomonads at the species level (13) and at the level of genotypic subspecies with known variations in biocontrol activities $(33,35,46$, 57). To more directly link differences in genotype with differences in biocontrol phenotype, one can analyze variants in genes closely related to biocontrol function, as has been done for several different antibiotic biosynthesis genes $(14,40,57)$. However, the linkage between readily assayable genotype and biocontrol phenotype will not always be absolute. This is because small and unmeasured changes in genome sequence may confound the associations. For example, phase variation in some pseudomonad populations can regulate secretion of secondary metabolites that can mediate plant pathogen suppression $(8,66)$. And, spontaneous mutations in the gacS and gacA genes of different biocontrol strains can arise in the rhizosphere, resulting in substantial subpopulations that are deficient in secondary metabolite biosynthesis and altered colonization potential $(9,61)$. The significance of genetic variation within functionally distinct subspecies of biocontrol pseudomonads (e.g., those that produce DAPG) has yet to be fully exploited for applied biological control. For example, now that multiple distinct genotypes of DAPG-producing pseudomonads have been identified, standardized collections of these known variants need to be systematically assayed for efficacy in controlling diseases in different cropping systems.

Factors affecting the distribution of biocontrol pseudomonads. Comprehensive culture-based studies of the rhizosphere have indicated that individual plants harbor mixed populations of pseudomonads, many of which can suppress plant pathogens in vitro $(3,4,48,60)$. However, given that complex interactions between rhizosphere bacteria can significantly affect the expression of biocontrol activities (53), it is generally unclear to what extent these different populations actually contribute to pathogen sup- pression under typical growing conditions. Clearly, biasing population structure through inoculation with biocontrol bacteria can lead to significant disease suppression in the field, especially when significant populations colonize the target tissues. However, it seems reasonable to assume that multiple abiotic and biotic factors will affect the abundance and activities of native biocontrol pseudomonads. Thus, a key area of future research will focus on defining the environmental conditions that significantly alter the distribution of biocontrol pseudomonads.

To date, a number of studies have characterized the environmental factors that can affect the abundance of different pseudomonad populations on plant surfaces. Above ground, colonization of newly emerged tissues is rapid and promoted by rainfall, high humidity, ice nucleation activity, virulence, and host susceptibility $(26,27,70)$. Below ground, the relative abundance and diversity of plant-associated Pseudomonas spp. are known to vary with host species, cultivar, and plant tissue $(3,4,41,48)$ as well as soil type, structure, and fertility $(5,36,52)$. Soil temperature and moisture also can affect root colonization and activities of biocontrol pseudomonads in significant ways $(20,62)$. The influence of plant species on root colonization appears to be particularly important in determining colonization of specific bacterial populations that might lead to biocontrol. For example, Mazzola and Gu (42) showed that wheat plants, which can harbor significant populations of biocontrol pseudomonads, grown in orchard soils suffering from apple replant disease can increase the abundance of Pseudomonas spp. and reduce disease pressure. Large-scale surveys of corn and soybean fields in Ohio have revealed that soil type and crop host play key roles in determining the degree of root colonization by native populations of biocontrol pseudomonads (45). In total, these studies have revealed several key factors that influence the abundance of biocontrol pseudomonads in agricultural systems.

In my laboratory, we are investigating the associations between native populations of pseudomonads that produce the antibiotic compound DAPG, plant health, and crop productivity in different cropping systems. Our data indicate that, in most instances, native populations of DAPG producers are positively correlated with corn stand and yields (D. Rotenberg and B. B. McSpadden Gardener, unpublished data). This is consistent with the hypothesis that native populations of DAPG producers contribute to maintaining plant health by suppressing pathogens (69). However, farm management practices can also significantly alter the relative abundance of biocontrol pseudomonads by simply altering the soil environment. For example, a comparison of continuously cropped versus rotated corn and soybean fields, planted under notill conditions, has shown that DAPG producers are more abundant under conditions of elevated soilborne disease pressure (Table 1). In this particular instance, soil moisture was elevated and soil temperatures depressed in response to elevated levels of corn residue. This led to elevated levels of Pythium infections and lower stands of both corn and soybeans following previous corn crops. An earlier study also indicated that the abundance of DAPG producers was increased following root infection by the take-all fungus, Gaeumannomyces graminis var. tritici (47). That study also provided evidence that shifts in the abundance of several bacterial populations, including other fluorescent pseudomonads, may facilitate pathogen suppression by DAPG-producing Pseudomonas spp. Other recent work has shown that compost amendments can significantly increase soil fertility and the abundance of DAPG producers in the rhizosphere while having varying effects on crop stand and vigor on a per plot basis (M. S. Benitez, D. Rotenberg, A. Camp, and B. B. McSpadden Gardener, unpublished data).

While it is currently unclear whether changes in rhizosphere bacterial community structure associated with pathogen infection generally lead to subsequent pathogen suppression, we hypothesize that competitive saprophytes that use antibiotics to secure 
access to consumable resources will increase as a result of the "collateral damage" caused by invading root pathogens. The net effect might be to slow pathogen ingress and/or reduce the viability of pathogen biomass located proximal to these competitive saprophytes. In some systems, this competition between pathogens and opportunistic saprophytes may lead to the development of long-lasting disease suppression (e.g., take-all decline) $(15,56)$. However, it seems unlikely that continuous cropping will typically lead to pseudomonad-based disease suppressive soils. In the continuous no-till corn fields described above, net pathogen fitness exceeded that of their bacterial competitors, and various root diseases continued to increase in severity over the 5 years for which monoculture was maintained. Thus, in addition to crop and soil type, crop health and cropping system will also influence the abundance and activities of specific populations of biocontrol pseudomonads.

Interactions with plants, insects, and microbes. Pseudomonas strains with the capacity to promote plant health have been described as biocontrol agents and plant-growth promoting (rhizo)bacteria. Collectively, they can be considered opportunistic mutualists, offering their plant hosts additional fortification against pathogens albeit on uncertain terms. Their beneficial effects result from the expression of multiple activities that act to directly and indirectly inhibit pathogen activities. Direct antagonism is largely mediated by antibiotic production $(25,55)$, which is hypothesized to be a primary determinant in specific suppression of soilborne diseases in various systems $(15,59,69)$. Whereas most studies have focused on suppression of fungi and oomycetes, others have shown that plant-pathogenic nematodes may also be suppressed by the production of various inhibitory compounds $(12,68)$. Most biocontrol strains are known to produce one or more antibiotic factors. And while genomic analyses are increasing the depth of our knowledge of the physiology of individual strains (37), the full spectrum of metabolites and the amounts of each secreted under typical cropping conditions remains a mystery. Competition for nutrients may also be important, but its quantitative contribution to biological control is difficult to measure. Indeed, predicting biocontrol efficacy from in vitro assays has not provided consistent results $(17,28)$. Indirect antagonism is largely mediated by the stimulation of host defenses (1). Although little is known about the factors that influence the expression of these activities and the specific conditions under which they promote plant health in the field, a large number of investigations point to the complexity of ecological interactions that can alter the relationships between Pseudomonas spp., their plant hosts, and plant pathogens.
Diverse rhizosphere microbes and their plant hosts can secrete multiple metabolites that can alter gene expression (53) and may, ultimately, alter the physiology of biocontrol pseudomonads, soilborne plant pathogens, and their plant hosts in significant ways. Different Pseudomonas spp. are capable of producing a variety of ecologically significant compounds, including antibiotics, plant hormones, nutrient chelators, exoenzymes, and signal molecules (54). Such secreted compounds can act to suppress pathogen activity via antibiosis and competition, and some may also stimulate plant host defenses (1). Interestingly, it has been suggested that such molecules are more frequently expressed by plant-associated pseudomonads as opposed to soilborne pseudomonads (21). Furthermore, gene expression required for the biosynthesis of such compounds has been shown to be up-regulated in the rhizosphere $(23,51)$. Beyond the diversity of compounds that might mediate interspecies interactions, it is also apparent that some compounds can have multiple effects on the community. For example, DAPG has been shown to inhibit the growth of diverse pathogens, stimulate plant host defenses, and stimulate amino acid uptake in roots (54). In turn, the biosynthesis of DAPG can be affected by a variety of abiotic $(19,52)$ and biotic (51) variables, indicating that, quantitatively, its production is context dependent. Indeed, the expression of DAPG-mediated biocontrol activities can be altered by pathogens $(18,50,64)$, other biocontrol strains $(34,38)$, and other members of soil and rhizosphere microbial communities that might otherwise be neutral or positive to plant health $(2,31,32,47)$. Additionally, the biosynthesis of DAPG may be affected by other compounds thought to contribute to biological control. For example, pyoluteorin (a pseudomonad-derived antibiotic) and salicylate (a compound that can stimulate host defense pathways) can be synthesized by several DAPG-producing pseudomonads, but act to repress biosynthesis of DAPG in culture (63). Such studies indicate the variety and potential complexity of intra- and interspecies microbial interactions that might modulate the expression of any single biocontrol mechanism. However, the frequency and magnitude of such interspecies interactions and, thus, their phenomenological significance have not been assessed under field conditions. Such studies might lead to a more compelling description of rhizosphere ecology and reveal why soilborne diseases are not consistently controlled through inoculation with biocontrol agents.

Current applications of biocontrol pseudomonads and prospects for improvement. Strains of fluorescent pseudomonads have been found that suppress a wide variety of plant diseases. Thus, there is substantial interest in developing some of these into biopesticides, to be used alone or in combination with

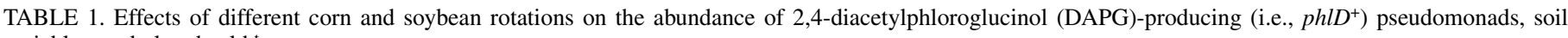
variables, and plant health ${ }^{t}$

\begin{tabular}{|c|c|c|c|c|c|c|c|}
\hline Rotation $^{\mathrm{u}}$ & $\log p h l D^{+\mathrm{v}}$ & $\%$ phlD ${ }^{+\mathrm{w}}$ & $\begin{array}{c}\text { Incidence }{ }^{\mathrm{x}} p h l D^{+} \\
>\log 5 / \mathrm{g}\end{array}$ & $\begin{array}{c}\% \text { Volumetric } \\
\text { water content }^{\mathrm{y}}\end{array}$ & $\begin{array}{c}\text { Soil temperature } \\
\left({ }^{\circ} \mathrm{C}\right)\end{array}$ & $\begin{array}{c}\text { Root fresh } \\
\text { weight }(\mathrm{mg})\end{array}$ & $\begin{array}{l}\text { Pythium } \\
\text { infection }^{z}\end{array}$ \\
\hline $\mathrm{CCC} \underline{\mathrm{C}}$ & $5.1 \mathrm{a}$ & $20 \mathrm{~b}$ & 0.67 & $22.5 b$ & $21.5 \mathrm{a}$ & $370 \mathrm{c}$ & $4.4 \mathrm{~d}$ \\
\hline $\operatorname{SCS} \underline{\bar{C}}$ & $4.9 \mathrm{a}$ & $6 a$ & 0.43 & $19.5 \mathrm{a}$ & $22.3 \mathrm{~b}$ & $531 \mathrm{~d}$ & $3.9 \mathrm{c}$ \\
\hline CSC $\underline{S}$ & $5.5 \mathrm{~b}$ & $60 \mathrm{c}$ & 0.67 & $21.8 \mathrm{a}$ & $21.9 \mathrm{a}$ & $177 \mathrm{a}$ & $2.9 \mathrm{~b}$ \\
\hline SSS $\underline{S}$ & $5.1 \mathrm{a}$ & $18 \mathrm{~b}$ & 0.50 & $19.4 \mathrm{a}$ & $23.0 \mathrm{~b}$ & $245 \mathrm{~b}$ & $2.4 \mathrm{a}$ \\
\hline
\end{tabular}

${ }^{\mathrm{t}}$ Mean values are tabulated, and for each column, values followed by different letters are significantly different based on Dunn's multiple range test $(P<0.01)$.

u Cropping sequence of corn (C) and soybeans (S) from 2001 through 2004. The crop assayed in 2004 is underlined.

${ }^{v}$ Population size of DAPG-producing Pseudomonas spp. estimated by the polymerase chain reaction-based assay described by McSpadden Gardener et al. (45).

${ }^{w}$ Relative abundance of DAPG-producing pseudomonads expressed as a percentage of all cultured pseudomonads.

${ }^{\mathrm{x}}$ Incidence of plants harboring more than $10^{5} \mathrm{phlD^{+ }}$ pseudomonads per gram of root (fresh weight).

y Volumetric water content measured at the time of sampling using radio interferometry.

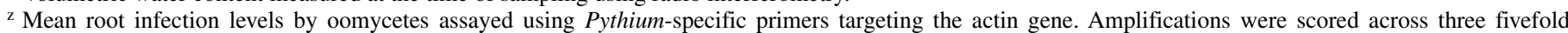
dilutions on a scale from 0 (no amplification) to 6 (maximum amplification in most dilute samples).

v Population size of DAPG-producing Pseudomonas spp. estimated by the polymerase chain reaction-based assay described by McSpadden Gardener et al. (45).

${ }^{w}$ Relative abundance of DAPG-producing pseudomonads expressed as a percentage of all cultured pseudomonads.

${ }^{x}$ Incidence of plants harboring more than $10^{5}$ phlD ${ }^{+}$pseudomonads per gram of root (fresh weight).

y Volumetric water content measured at the time of sampling using radio interferometry.

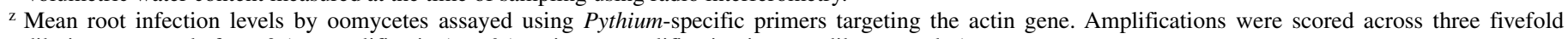
dilutions on a scale from 0 (no amplification) to 6 (maximum amplification in most dilute samples). 
chemical pesticides. To date, commercial interest in Pseudomonas biocontrol strains has been more limited than for spore-forming microbes such as Bacillus and Trichoderma. Nonetheless, several pseudomonad strains are currently registered with the U.S. Environmental Protection Agency as biopesticides and have been made commercially available to growers (22). These include $P$. chlororaphis strain 63-28 for control of wilt diseases and stem and root rot; $P$. chlororaphis TX-1 for control of turfgrass diseases; P. syringae strain ESC-10 for control of fungal postharvest diseases; $P$. fluorescens strain A506 for control of fire blight and russeting of pome fruits; and combinations of $P$. fluorescens strains A506 and 1629RS and P. syringae 742RS for prevention of frost-induced damage on several crops. Additionally, the extensive field testing of additional strains by different academic and government laboratories (11) indicates that additional opportunities exist for commercial development of pseudomonads for the biological control of a variety of crop diseases. However, to do so, more comprehensive evaluations of the cost and benefits of experimental strains relative to other disease control strategies need to be done in order for their commercial potential to be properly evaluated.

The relative safety and environmental impact of natural and genetically engineered pseudomonad biocontrol strains has been thoroughly evaluated. As with any disease control measure, one can expect application of biocontrol pseudomonads to alter the structure of plant-associated microbial communities. Indeed, the goal of biological control is to reduce plant pathogen activity, often by suppressing pathogen abundance directly or indirectly. The magnitude of disturbances to nontarget organisms that may be caused by inoculation is generally considered to be small and transient $(6,24,49)$. This is consistent with the lack of negative impacts associated with widespread rhizobial inoculation of legumes, and it is in stark contrast to the dramatic shifts in microbial community structure that results following the application of more conventional farm practices. Given the widespread distribution of pseudomonads with biocontrol activities in the environment, it may be possible to develop targeted biocontrol strategies. For example, strains of DAPG-producing pseudomonads have been recovered from most agricultural soils. We hypothesize that targeted isolation and reintroduction of individual strains on a site-specific basis would provide an approach that minimizes the potential disruption of microbial community structures by virtue of avoiding the introduction of nonnative strains. Recently, we implemented such an approach and found it to be effective at increasing productivity in conventional and organic soybean fields $(43,44)$.

A multitude of possibilities still exists for the successful application and management of Pseudomonas-mediated biological control of plant pathogens; however, more research into the microbial ecology of the genus will be required to ensure success of future biocontrol applications. The path from functional screens to the characterization of genetic mechanisms has proven useful in the past, but more directed screens may point the way in the future. Intensive studies of DAPG producers have shown that subspecies diversity is extensive and may be tapped for applications to different plant disease problems. The use of biocontrolrelated gene markers to identify novel but functionally related strains could rapidly accelerate strain discovery. However, currently, only genes involved in antibiotic biosynthesis have been revealed as useful candidates for such directed selection procedures. Characterizing the genetic basis for the pseudomonadmediated induction of plant host defense pathways should provide additional useful markers, opening up the possibility of further expanding collections related to the most effective pseudomonad biocontrol strains. Biocontrol markers will also be useful for mapping the distribution of biocontrol populations in production environments. Further investigating the biogeography of various biocontrol populations can be useful for identifying novel genetic variants especially from diverse environments, which then can be used for directed screening programs.

Distinct genotypes appear to be endemic to specific geographic locations (10), so systematic bioprospecting of soils and plants from different ecosystems should provide a wealth of novel and potentially useful biocontrol strains. New screening programs might focus on evaluating the utility of a core set of strains for application on a single crop and its most important pathogens. This could lead to commodity-specific applications where strain testing is tailored toward the salient features of a more comprehensive pest management program. A greater understanding of which biological control and pathogen populations are present and active in a given area also may be useful for identifying locations with the greatest probability of responding to inoculations, e.g., those where native populations of biocontrol pseudomonads are low.

The limited viability of Pseudomonas spp. has hindered practical applications, especially in those systems where on-farm applications are not considered economically feasible. However, the use of strains with superior colonization potential (e.g., Q9r1-96) (56) may allow for workable applications. For example, we have developed a two-step inoculation process that allows for convenient in-hopper seed treatments with proven yield increasing potential $(43,44$, unpublished data). The process uses partially hydrated and autoclaved soybean seeds as a matrix for keeping the DAPG-producing pseudomonads viable for 6 months or more. Two to seven days prior to planting, the farmer activates the inoculum by the addition of a specified amount of chlorinefree water, creating a condition allowing for the multiplication of the bacteria. At planting, the DAPG producers are rinsed from the matrix and diluted to a level that provides for seedling root colonization following spray treatment and mixing of the seed in the hopper. Further research on the ecology of biocontrol pseudomonads may reveal the underlying causes or contexts under which biological control fails or, alternatively, is most successful. Such knowledge will be useful for further developing biocontrol applications with increased efficacy and consistency.

\section{ACKNOWLEDGMENTS}

This work was supported, in part, by funds provided by the Organic Farming Research Foundation and the National Research Initiative of the U.S. Department of Agriculture-Cooperative State Research, Education and Extension Service grant 2002-35107-12271.

\section{LITERATURE CITED}

1. Bakker, P. A. H. M., Pieterse, C. M. J., and van Loon, L. C. 2007. Induced systemic resistance by fluorescent Pseudomonas spp. Phytopathology 97:239-243.

2. Barea, M., Andrade, G., Bianciotto, V., Dowling, D., Lohrke, S., Bonfante, P., O'Gara, F., and Azcon-Aguilar, C. 1998. Impact on arbuscular mycorrhiza formation of Pseudomonas strains used as inoculants for biocontrol of soil-borne fungal plant pathogens. Appl. Environ. Microbiol. 64:2304-2307.

3. Berg, G., Krechel, A., Ditz, M., Sikora, R., Ulrich, A., and Hallmann, J. 2005. Endophytic and ectophytic potato-associated bacterial communities differ in structure and antagonistic function against plant pathogenic fungi. FEMS Microbiol. Ecol. 51:215-229.

4. Berg, G., Roskot, N., Steidle, A., Eberl, L., Zock, A., and Smalla, K. 2002. Plant-dependent genotypic and phenotypic diversity of antagonistic rhizobacteria isolated from different Verticillium host plants. Appl. Environ. Microbiol. 68:3328-3338.

5. Bergsma-Vlami, M., Prins, M. E., and Raaijmakers, J. M. 2005. Influence of plant species on population dynamics, genotypic diversity and antibiotic production in the rhizosphere by indigenous Pseudomonas spp. FEMS Microbiol. Ecol. 52:59-69.

6. Blouin-Bankhead, S., Landa, B. B., Lutton, E., Weller, D. M., and McSpadden Gardener, B. B. 2004. Minimal changes in rhizobacterial population structure following root colonization by wild type and transgenic biocontrol strains. FEMS Microbiol. Ecol. 49:307-318. 
7. Bossis, E., Lemanceau, P., Latour, X., and Gardan, L. 2000. The taxonomy of Pseudomonas fluorescens and Pseudomonas putida: Current status and need for revision. Agronomie (Paris) 20:51-63.

8. Bull, C. T., Duffy, B., Voisard, C., Défago, G., Keel, C., and Haas, D. 2001. Characterization of spontaneous gacS and gacA regulatory mutants of Pseudomonas fluorescens biocontrol strain CHA0. Antonie Van Leeuwenhoek 79:327-336.

9. Chancey, S. T., Wood, D. W., Pierson, E. A., and Pierson, L. S., III. 2002. Survival of GacS/GacA mutants of the biological control bacterium Pseudomonas aureofaciens 30-84 in the wheat rhizosphere. Appl. Environ. Microbiol. 68:3308-3314.

10. Cho, J.-C., and Tiedje, J. M. 2000. Biogeography and degree of endemicity of fluorescent Pseudomonas strains in soil. Appl. Environ. Microbiol. 66:5448-5456.

11. Cook, R. J., Weller, D. M., Yousssef El-Bann, A., Vakoch, D., and Zhang, H. 2002. Yield responses of direct-seeded wheat to rhizobacteria and fungicide seed treatments. Plant Dis. 86:780-784.

12. Cronin, D., Moenne-Loccoz, Y., Fenton, A., Dunne, C., Dowling, D. N., and O'Gara, F. 1997. Role of 2,4-diacetylphloroglucinol in the interactions of the biocontrol pseudomonad strain F113 with the potato cyst nematode Globodera rostochiensis. Appl. Environ. Microbiol. 63:13571361.

13. Dawson, S. L., Fry, J. C., and Dancer, B. N. 2002. A comparative evaluation of five typing techniques for determining the diversity of fluorescent pseudomonads. J. Microbiol. Methods 50:9-22.

14. de Souza, J. T., and Raaijmakers, J. M. 2003. Polymorphisms within the prn $\mathrm{D}$ and pltC genes from pyrrolnitrin and pyoluteorin-producing Pseudomonas and Burkholderia spp. FEMS Microbiol. Ecol. 43:21-34.

15. de Souza, J. T., Weller, D. M., and Raaijmakers, J. M. 2003. Frequency, diversity, and activity of 2,4-diacetylphloroglucinol-producing fluorescent Pseudomonas spp. in Dutch take-all decline soils. Phytopathology 93:5463.

16. Delorme, S., Pilipot, L., Edel-Hermann, Deulvot, C., Mougel, C., and Lemanceau, P. 2003. Comparative genetic diversity of $n a r G$, nosZ, and $16 \mathrm{~S}$ rRNA genes in fluorescent pseudomonads. Appl. Environ. Microbiol. 69:1004-1012.

17. Dianese, A. C., Ji, P., and Wilson, M. 2003. Nutritional similarity between leaf-associated nonpathogenic bacteria and the pathogen is not predictive of efficacy in biological control of bacterial spot of tomato. Appl. Environ. Microbiol. 69:3484-3491.

18. Duffy, B., Keel, C., and Défago, G. 2004. Potential role of pathogen signaling in multitrophic plant-microbe interactions involved in disease protection. Appl. Environ. Microbiol. 70:1836-1842.

19. Duffy, B. K., and Défago, G. 1999. Environmental factors modulating antibiotic and siderophore biosynthesis by Pseudomonas fluorescens biocontrol strains. Appl. Environ. Microbiol. 65:2429-2438.

20. Egamberdiyeva, D., and Hoflich, G. 2003. Influence of growth-promoting bacteria on the growth of wheat in different soils and temperatures. Soil Biol. Biochem. 35:973-978.

21. Elasri, M., Delorme, S., Lemanceau, P., Stewart, G., Laue, B., Glickmann, E., Oger, P., and Dessaux, Y. 2001. Acyl-homoserine lactone production is more common among plant-associated Pseudomonas spp. than among soilborne Pseudomonas spp. Appl. Environ. Microbiol. 67:1198-1209.

22. Fravel, D. R. 2005. Commercialization and implementation of biocontrol. Annu. Rev. Phytopathol. 43:337-359.

23. Gal, M., Preston, G. M., Massey, R. C., Spiers, A. J., and Rainey, P. B. 2003. Genes encoding a cellulosic polymer contribute toward the ecological success of Pseudomonas fluorescens SBW25 on plant surfaces. Mol. Ecol. 12:3109-3121.

24. Glandorf, D. C. M., Verheggen, P., Jansen, T., Jorritsma, J., Smit, E., Leeflang, P., Wernars, K., Thomashow, L. S., Laureijs, E., Thomas-Oates, J. E., Bakker, P. A. H. M., and van Loon, L. C. 2001. Effect of genetically modified Pseudomonas putida WCS358r on the fungal rhizosphere microflora of field-grown wheat. Appl. Environ. Microbiol. 67:33713378.

25. Haas, D., and Keel, C. 2003. Regulation of antibiotic production in rootcolonizing Pseudomonas spp. and relevance for biological control of plant disease. Annu. Rev. Phytopathol. 41:117-153.

26. Hirano, S., Charkowski, S. A. O., Collmer, A., Willis, D. K., and Upper, C. D. 1999. Role of the Hrp type III protein secretion system in growth of Pseudomonas syringae pv. syringae B728a on host plants in the field. Proc. Natl. Acad. Sci. USA 96:9851-9856.

27. Hirano, S. S., Baker, L. S., and Upper, C. D. 1996. Raindrop momentum triggers growth of leaf-associated populations of Pseudomonas syringae on field-grown snap bean plants. Appl. Environ. Microbiol. 62:25602566.

28. Janisiewicz, W. J. 1996. Ecological diversity, niche overlap and coexistence of antagonists used in developing mixtures for biocontrol of post-harvest diseases of apples. Phytopathology 86:473-479.

29. Janisiewicz, W. J., and Jeffers, S. N. 1997. Efficacy of commercial formulation of two biofungicides for control of blue mold and gray mold of apples in cold storage. Crop Prot. 16:629-633.

30. Janisiewicz, W. J., and Marchi, A. 1992. Control of storage rots on various pear cultivars with saprophytic strain of Pseudomonas syringae. Plant Dis. 76:555-560.

31. Keel, C., Ucurum, Z., Michaux, P., Adrian, M., and Haas, D. 2002. Deleterious impact of a virulent bacteriophage on survival and biocontrol activity of Pseudomonas fluorescens strain CHA0 in natural soil. Mol. Plant-Microbe Interact. 15:567-576.

32. Knox, O. G. G., Killharn, K., Artz, R. R. E., Mullins, C., and Wilson, M. 2004. Effect of nematodes on rhizosphere colonization by seed-applied bacteria. Appl. Environ. Microbiol. 70:4666-4671.

33. Landa, B. B., Cachinero-Diaz, J. M., Lemanceau, P., Jimenez-Diaz, R. M., and Alabouvette, C. 2002. Effect of fusaric acid and phytoanticipins on growth of rhizobacteria and Fusarium oxysporum. Can. J. Microbiol. 48:971-985

34. Landa, B. B., Mavrodi, D. M., Thomashow, L. S., and Weller, D. M. 2003. Interactions between strains of 2,4-diacetylphloroglucinol-producing Pseudomonas fluorescens in the rhizosphere of wheat. Phytopathology 93:982-994.

35. Landa, B. B., Mavrodi, O. V., Raaijmakers, J. M., McSpadden Gardener, B. B., Thomashow, L. S., and Weller, D. M. 2002. Differential ability of genotypes of 2,4-diacetylphloroglucinol-producing Pseudomonas fluorescens strains to colonize the roots of pea plants. Appl. Environ. Microbiol. 68:3226-3237.

36. Latour, X., Phillipot, L., Corberand, T., and Lemanceau, P. 1999. The establishment of an introduced community of fluorescent pseudomonads in the soil and in the rhizosphere is affected by the soil type. FEMS Microbiol. Ecol. 30:163-170.

37. Loper, J. E., Kobayashi, D. Y., and Paulsen, I. T. 2007. The genomic sequence of Pseudomonas fluorescens Pf-5: Insights into biological control. Phytopathology 97:233-238.

38. Lutz, M. P., Wenger, S., Maurhofer, M., Défago, G., and Duffy, B. 2004. Signaling between bacterial and fungal biocontrol agents in a strain mixture. FEMS Microbiol. Ecol. 48:447-455.

39. Mavrodi, D. V., Mavrodi, O. V., McSpadden Gardener, B. B., Landa, B. B., Weller, D. M., and Thomashow, L. S. 2002. Identification of differences in genome content among phlD-positive Pseudomonas fluorescens strains by using PCR-based subtractive hybridization. Appl. Environ. Microbiol. 68:5170-5176.

40. Mavrodi, O. V., McSpadden Gardener, B. B., Mavrodi, D. V., Bonsall, R. F., Weller, D. M., and Thomashow, L. S. 2001. Genetic diversity of phlD from 2,4-diacetylphloroglucinol-producing fluorescent Pseudomonas spp. Phytopathology 91:35-43.

41. Mazzola, M., Funnell, D. L., and Raaijmakers, J. M. 2004. Wheat cultivarspecific selection of 2,4-diacetylphloroglucinol-producing fluorescent Pseudomonas species from resident soil populations. Microbiol. Ecol. 48:338-348.

42. Mazzola, M., and Gu, Y.-H. 2000. Impact of wheat cultivation on microbial communities from replant soils and apple growth in greenhouse trials. Phytopathology 90:114-119.

43. McSpadden Gardener, B., Benitez, M.-S., Camp, A., and Zumpetta, C. 2006. Evaluation of a seed treatment containing a phlD+ strain of Pseudomonas fluorescens on organic soybeans, 2005. Biol. Cult. Tests Rep. 21:FC046.

44. McSpadden Gardener, B., Kroon van Diest, C., and Beuerlein, J. 2006. Evaluation of biological seed treatments containing phlD+ strains of Pseudomonas fluorescens on soybeans grown in Ohio, 2005. Biol. Cult. Tests Rep. 21:FC045.

45. McSpadden Gardener, B. B., Gutierrez, L., Joshi, R., Edema, R., and Lutton, E. 2005. Distribution and biocontrol potential of phlD pseudomonads in corn and soybean fields. Phytopathology 95:715-724.

46. McSpadden Gardener, B. B., Schroeder, K. L., Kalloger, S. E., Raaijmakers, J. M., Thomashow, L. S., and Weller, D. M. 2000. Genotypic and phenotypic diversity of phlD-containing Pseudomonas strains isolated from the rhizosphere of wheat. Appl. Environ. Microbiol. 66:1939-1946

47. McSpadden Gardener, B. B., and Weller, D. M. 2001. Changes in populations of rhizosphere bacteria associated with take-all disease of wheat. Appl. Environ. Microbiol. 67:4414-4425.

48. Misko, A. L., and Germida, J. J. 2002. Taxonomic and functional diversity of pseudomonads isolated from the roots of field-grown canola. FEMS Microbiol. Ecol. 42:399-407.

49. Möenne-Loccoz, Y., Tichy, H., O’Donnell, A., Simon, R., and O'Gara, F. 2001. Impact of 2,4-diacetylphloroglucinol-producing biocontrol strain Pseudomonas fluorescens F113 on intraspecific diversity of resident culturable fluorescent pseudomonads associated with the roots of fieldgrown sugar beet seedlings. Appl. Environ. Microbiol. 67:3418-3425.

50. Notz, R., Maurhofer, M., Dubach, H., Haas, D., and Défago, G. 2002. Fusaric acid-producing strains of Fusarium oxysporum alter 2,4- 
diacetylphloroglucinol biosynthetic gene expression in Pseudomonas fluorescens $\mathrm{CHA} 0$ in vitro and in the rhizosphere of wheat. Appl. Environ. Microbiol. 68:2229-2235.

51. Notz, R., Maurhofer, M., Schnider-Keel, U., Duffy, B., Haas, D., and Défago, G. 2001. Biotic factors affecting expression of the 2,4-diacetylphloroglucinol biosynthesis gene phlA in Pseudomonas fluorescens biocontrol strain CHA0 in the rhizosphere. Phytopathology 91:873-881.

52. Ownley, B. H., Duffy, B. K., and Weller, D. M. 2003. Identification and manipulation of soil properties to improve the biological control performance of phenazine-producing Pseudomonas fluorescens. Appl. Environ. Microbiol. 69:3333-3343.

53. Pierson, L. S., III, and Pierson, E. A. 2007. Roles of diffusible signals in communication among plant-associated bacteria. Phytopathology 97:227232.

54. Preston, G. M. 2004. Plant perceptions of plant growth-promoting Pseudomonas. Philos. Trans. R. Soc. London B Biol. Sci. 359:907-918.

55. Raaijmakers, J. M., Vlami, M., and de Souza, J. T. 2002. Antibiotic production by bacterial biocontrol agents. Antonie Van Leeuwenhoek 81:537-547.

56. Raaijmakers, J. M., and Weller, D. M. 2001. Exploiting genotypic diversity of 2,4-diacetylphloroglucinol-producing Pseudomonas spp.: Characterization of superior root-colonizing P. fluorescens strain Q8r1-96. Appl. Environ. Microbiol. 67:2545-2554.

57. Ramette, A., Frapolli, M., Défago, G., and Möenne-Loccoz, Y. 2003. Phylogeny of HCN synthase-encoding hcnBC genes in biocontrol fluorescent pseudomonads and its relationship with host plant species and $\mathrm{HCN}$ synthesis ability. Mol. Plant-Microbe Interact. 16:525-535.

58. Ramette, A., Möenne-Loccoz, Y., and Défago, G. 2001. Polymorphism of the polyketide synthase gene phlD in biocontrol fluorescent pseudomonads producing 2,4-diacetylphloroglucinol and comparison of PhlD with plant polyketide synthases. Mol. Plant-Microbe Interact. 14:639-652.

59. Ramette, A., Möenne-Loccoz, Y., and Défago, G. 2003. Prevalence of fluorescent pseudomonads producing antifungal phloroglucinols and/or hydrogen cyanide in soils naturally suppressive or conducive to tobacco black root rot. FEMS Microbiol. Ecol. 44:35-43.

60. Ross, I. L., Alami, Y., Harvey, P. R., Achouak, W., and Ryder, M. H. 2000. Genetic diversity and biological control activity of novel species of closely related pseudomonads isolated from wheat field soils in South Australia. Appl. Environ. Microbiol. 66:1609-1616.

61. Sanchez-Contreras, M., Martin, M., Villacieros, M., O’Gara, F., Bonilla, I., and Rivilla, R. 2002. Phenotypic selection and phase variation occur during alfalfa root colonization by Pseudomonas fluorescens F113. J.
Bacteriol. 184:1587-1596.

62. Schmidt, C. S., Agostini, F., Leifert, C., Killham, K., and Mullins, C. E. 2004. Influence of soil temperature and matric potential on sugar beet seedling colonization and suppression of Pythium damping-off by the antagonistic bacteria Pseudomonas fluorescens and Bacillus subtilis. Phytopathology 94:351-363.

63. Schnider-Keel, U., Seematter, A., Maurhofer, M., Blumer, C., Duffy, B., Gigot-Bonnefoy, C., Reimmann, C., Notz, R., Défago, G., Haas, D., and Keel, C. 2000. Autoinduction of 2,4-diacetylphloroglucinol biosynthesis in the biocontrol agent Pseudomonas fluorescens CHA0 and repression by the bacterial metabolites salicylate and pyoluteorin. J. Bacteriol. 182:1215-1225.

64. Schouten, A., van den Berg, G., Edel-Hermann, V., Steinberg, C., Gautheron, N., Alabouvette, C., de Vos, C. H., Lemanceau, P., and Raaijmakers, J. M. 2004. Defense responses of Fusarium oxysporum to 2,4-diacetylphloroglucinol, a broad-spectrum antibiotic produced by Pseudomonas fluorescens. Mol. Plant-Microbe Interact. 17:1201-1211.

65. Skerman, V. B. D., McGoawna, V., and Sneath, P. H. A. 1980. Approved lists of bacterial names. Int. J. Syst. Bacteriol. 30:225-420.

66. van den Broek, D., Chin-A-Woeng, T. F. C., Eijkemans, K., Mulders, I. H. M., Bloemberg, G. V., and Lugtenberg, B. J. 2003. Biocontrol traits of Pseudomonas spp. are regulated by phase variation. Mol. Plant-Microbe Interact. 16:1003-1012.

67. Wang, C., Ramette, A., Punjasamarnwong, P., Zala, M., Natsch, A., Möenne-Loccoz, Y., and Défago, G. 2001. Cosmopolitan distribution of phlD-containing dicotyledonous crop-associated biocontrol pseudomonads of worldwide origin. FEMS Microbiol. Ecol. 37:105-116.

68. Wechter, W. P., Glandorf, D. C. M., Derrick, W. C., Leverentz, B., and Kluepfel, D. A. 2001. Identification of genetic loci in a rhizosphereinhabiting, species of Pseudomonas involved in expression of a phytoparasitic nematode ovicidal factor. Soil Biol. Biochem. 33:1749-1758.

69. Weller, D. M., Raaijmakers, J. M., McSpadden Gardener, B. B., and Thomashow, L. S. 2002. Microbial populations responsible for specific soil suppressiveness to plant pathogens. Annu. Rev. Phytopathol. 40:309348.

70. Wilson, M., Hirano, S. S., and Lindow, S. E. 1999. Location and survival of leaf-associated bacteria in relation to pathogenicity and potential for growth within the leaf. Appl. Environ. Microbiol. 65:1435-1443.

71. Yamamoto, S., Kasai, H., Arnold, D. L., Jackson, R. W., Vivian, A., and Harayama, S. 2000. Phylogeny of the genus Pseudomonas: Intrageneric structure reconstructed from the nucleotide sequences of gyr $B$ and $r p o D$ genes. Microbiology 146:2385-2394. 